ISBN 978-93-84422-85-1

11th International Conference on Chemical, Agricultural, Biological and Environmental Sciences

(CABES-2018)

April 17-18, 2018 Kyoto (Japan)

\title{
Solid Waste Utilization of Tea Extract Industry as a Briquette and Super Capacitor based on Activated Carbon
}

\author{
Tiana Rafmiwati ${ }^{1 *}$, Joshua Foliadi $^{2}$ and Ayu Diah Padyanawati ${ }^{3}$ \\ Departement of Agroindustrial Technology, Bogor Agricultural University, Indonesia
}

\begin{abstract}
Waste is a major problem in many developing countries as in Indonesia. The amount of waste will increase along with the rapidity of human civilization and if it is not handled properly it will cause environmental problems. The accumulation of waste will narrow the existing land and will impact the industry. Super capacitors are energy storage devices that store energy electrostatically by polarizing an electrolyte compound. Electrochemical Double Layer Capacitor or super capacitor is an electrochemical capacitor that has high capacity and high energy density compared to regular capacitors and batteries. The super capacitor consists of 2 electrodes made of activated carbon, 1 electrolyte compound, 1 ion-removable separator but provides electrical insulation. The power density capability of the super capacitor is due to the surface area of the electrode material. Activated carbon is used because it has a large surface area for the electrode so that the super capacitor will have a higher capacity. The use of activated carbon as electrodes in super-capacitors because it has high conductivity, high surface area, corrosion resistance, stable at high temperature, regular pore structure, and it is cheap. Activated carbon is made from low-density materials such as wood, lignite, and lignin-containing materials such as agricultural waste. Tea extraction industries produce waste in the form of dregs tea that until now has not been utilized optimally to our best knowledge. Dregs tea can be used as briquettes with its yield and calorific value sequentially are $42 \%$ and 5544 cal/gram. The briquettes are made through the following procedures: 1.Preparing of raw materials, 2. Drying of the crushed materials, 3. Putting it on the briquette printer, 4. Carbonization. It shows that dregs tea can be utilized as an activated carbon with three stages; dehydration, carbonization, and activation. In this paper shows that the activated carbon can be used as a cheap source for the manufacture of super capacitor
\end{abstract}

Keywords: dregs tea, briquette, activated carbon, super capacitor

\section{Introduction}

The more advanced a country will be followed by a rising population and industry. Waste is defined as at the end of the product life cycle and is disposed of in landfills of industry. Most businesses explained waste as anything that does not create value [1]. The Types of waste industry produce is solid and liquid waste. Other kinds of waste are hazardous or harmful waste, organic waste, and recyclable waste. According to Robert [2], United State is a leads country to produce waste because of each US citizens waste can produce 1600 pounds waste per year. The common waste that produced is municipal solid waste like household and some commercial waste, electronic waste, hazardous waste, and also recyclable waste [2]. Solid waste management is the number two largest segment in the sector after water and wastewater management, at US\$5.4 billion or $22.5 \%$ of the Asian environmental market in 2001 [3]. From this data are explained that solid waste is one of the main problem in Asia. Based on BPS, in 2015 Indonesia have 5438 food and drink industries and also 925 plastic industries. The largest industry amount is food and drink, it means the most waste in Indonesia from food and drink industry [4].

Tea is a popular source that uses in many daily life such as drink, cosmetic, food, and flavour. It found two varieties of tea, i.e. C. sinensis var. sinensis (China tea) is widely planted in China, Japan, and Taiwan, while C. sinensis var. assamica (Assam tea) grows rapidly in south and Southeast Asia, and more recently, Australia [5]. 
There are kinds of method can be used to produce tea in many countries. Chromatogram methods can be used to isolate and purify tannin for produce green tea, but the safest and convenient method of obtaining tea functional components is to extract them from naturally planted tea [6]. Japan usually used steam extraction (or distillation) of polyphenol from tea, steam distillation is often liked in many industries since it does not contain nonrenewable solvent or potentially toxic solvent contaminant, with associated solvent flammability and solvent recovery problems. In addition there is solvent extraction, but problems that are associated with this process can be undesirable residues of solvent may be left in the extracted tea [7]. There is a lot of product from green tea in Indonesia such as snack, drinking, and cosmetic. Indonesia usually used solvent extraction like ethanol for tea, and then the extract was separated by filtration and then evaporates the liquid [5].

PT Indesso Aroma Cileungsi- Bogor which is located in Cibubur Alternative street - Cileungsi KM 9, West Java, Indonesia produces extracts from tea and coffee. For tea leaf raw materials, the products produced are Green Tea Extract 725 and Black Tea Extract 726. Tea extract is produced in two different ways depending on the goal to be achieved. Extraction can be done with two types of solvents, i.e with water and alcohol (ethanol). The extraction results can be utilized as medicine and beverage industry. The resulting benefits are as an antioxidant and antiaging because it contains polyphenols. The resulting product is viscous liquid, while the side product is ethanol evaporate and dregs tea. The resulting ethanol evaporate is condensed and used as solvent for further extraction process. The dregs tea before disposal is carried out in the drying process to reduce the volume of waste disposal and leave no stinging odor in the final dump. But there's no utilization on the dregs tea. The waste that produced from the water-solvent extractions have normal color and odor such as tea brew while the ethanol-solvent extraction has a strong odor (typical of alcohol) and a more concentrated color. Tea waste from black tea productions have a more stinging smell, this due to fermentation process.

Tea waste carried out the drying process for three hours to separate the alcohol content in dregs tea before disposal. The separated alcohols can be reused while the tea dregs are thrown away without weighing and quality control. In one day, every type of product requires two extractors for the process in which each extractor processes $500 \mathrm{~kg}$ of tea leaves. The waste produced can be predicted in a day that is $\pm 1200 \mathrm{~kg}$ of dregs tea. Tea extraction production conducted by PT Indesso Aroma is increasing, this causes the tea waste which is solid waste from this product also increase. So far PT Indesso Aroma has only piled up the solid waste in an empty field around the factory. However, as the volume of solid waste continues to increase, the solution is to open the land to accommodate the waste. This is certainly not a good way of handling solid waste.

\section{Research Methodology}

The methodologies of research used in this study are arranged by three methods include applied research, literature study, and data collection.

\subsection{Applied Research}

Applied research aims at finding a solution for an immediate problem facing a society or an industrial/business organization. The problem in industry is the solid waste of dregs tea that accumulating in the landfill and harming the environment. In this research, we utilized the dregs tea to be fertilizer and briquette and test the feasibility to be commercialized.

\subsection{Literature Study}

Method of literature study is done with collecting actual data from book, journals, internet media, or other factual medias. This method is to identify the essential attribute of materials. The technique of collecting data with literature study is applied because the arrangement of this paper is qualitative. Reference is obtained from various types of journals on the internet. The reference is about:

- Description of super capacitor,

- Stages of processing activated carbon into super capacitor,

- Benefits owned of prospective products from solid waste. 


\subsection{Data Collection}

Collecting data in this paper are primary and secondary data. Primary data is collected through experiment. Secondary data means that authors get the actual data derived from books, journals, or internet media.

\section{Material and Methods}

The experiment was conducted in tea extract industry, PT Indesso Aroma, Cileungsi, Bogor, West Java, Indonesia. The experiment consisted of two kinds of solid waste from the extraction plant in PT Indesso Aroma, first is dregs tea from the water solvent and second is from the ethanol solvent.

Dregs tea from the water solvent can be utilize as a fertilizer. The materials that we need are 1 sack of tea waste $(30 \mathrm{~kg}$ ), chicken manure 1/8 sack, goat manure $1 / 8 \mathrm{sack}$, calcium carbonate, $1 / 4 \mathrm{~kg}$ of bran, and 2 glasses liquid fertilizer, and all the materials dissolve in 20 liters of water (PC1). For PC2 we need to dissolve 1 glass liqud fertilizer in 20 liters of water. First, stir calcium carbonate with bran, then separate. Second, Stir the tea waste, along with chicken and goat dung. After that add the mixture of bran and calcium carbonate to the surface of the waste and the dirt, and stir it well. Then, Pour PC 1 into first dough, then mix well. Next, Cover with a used sack for 5 days. After 5 days then pour PC 2, then stir until blended. Then Close for one week.

Dregs tea from the ethanol solvent can be utilize as a charcoal or briquette. First, Use a hammer mill to smooth the dregs tea into powder according to the characteristics required by the briquette printing machine, which is 3-5 mm. Second, dry the powder with Sawdust Dryer for tea dregs with water content of $40 \%$ to $12 \%$. After that, use the Sawdust Briquette Machine to make the briquette mold (cylinder, hexagonal, etc.). After that, collect 1 tonne print briquettes then carbonize them for 24 hours.

\section{Result and Discussion}

\subsection{Fertilizer from Tea Waste}

Compost fertilizer that has been fermented in PT Indesso Aroma for a month in terms of physical, already has the characteristics shown by successful compost fertilizer. The color produced black, formed loose granules, its temperature was around $40 \mathrm{o} \mathrm{C}$, the original form is not visible, no foul smell, appeared maggots, but the water content slightly more than it should. This is because composting is done in an open space so that water content can increase. Then in terms of chemistry has been tested the quality of Nitrogen, Phospor, and Potassium (NPK).

According to the analysis, the content of NPK present in the fertilizer from the industry, from this tea leaf waste meets the standard given by SNI (Indonesian National Standard). Nitrogen concentration of tea leaf waste fertilizer is $1.73 \%$ (as shown in table 1) and in accordance with the minimum of SNI, the content of $\mathrm{N}$ in compost is $0.4 \%$. Potassium concentration seen from $\mathrm{K} 2 \mathrm{O}$ content is $0.38 \%$ and in accordance with the minimum of SNI, $\mathrm{K} 2 \mathrm{O}$ content in compost is $0.2 \%$. Then the concentration of phosphorus seen from the content of $\mathrm{P} 2 \mathrm{O} 5$ is $0.56 \%$ and in accordance with the standard SNI at minimum in $0.1 \%$. So, the nutrients contained in artificial fertilizer from the dregs tea of water-solvent extraction at PT Indesso Aroma in accordance with minimum standards of SNI as shown in table 2.

TABLE I: Quality Analysis of Fertilizer (NPK) from PT Indesso Aroma Tea Waste

\begin{tabular}{|c|c|c|c|c|}
\hline \multirow{2}{*}{ Number } & \multirow{2}{*}{$\begin{array}{c}\text { Sample } \\
\text { Code }\end{array}$} & $\mathrm{N}$ & $\mathrm{P}$ & $\mathrm{K}$ \\
\cline { 3 - 5 } & $\mathrm{K}-1$ & 1.73 & 0.56 & 0.38 \\
\hline 1 & &
\end{tabular}


TABLE II: Compost Quality Standard according to SNI 19-7030-2004

\begin{tabular}{|c|c|c|c|c|}
\hline No & Parameter & Unit & Minimum & Maximum \\
\hline 1 & Nitrogen & $\%$ & 0.4 & - \\
\hline 2 & Phosphor & $\%$ & 0.1 & - \\
\hline 3 & Potassium & $\%$ & 0.2 & - \\
\hline
\end{tabular}

The compost fertilizer that was made in PT Indesso Aroma if it wants to be commercialized, it should be tested more comprehensive. Nutrient content or NPK parameter only as an indicator of agronomic value, which shows the efficiency of the land to be planted with the target of production to be achieved. So it must be done another quality test.

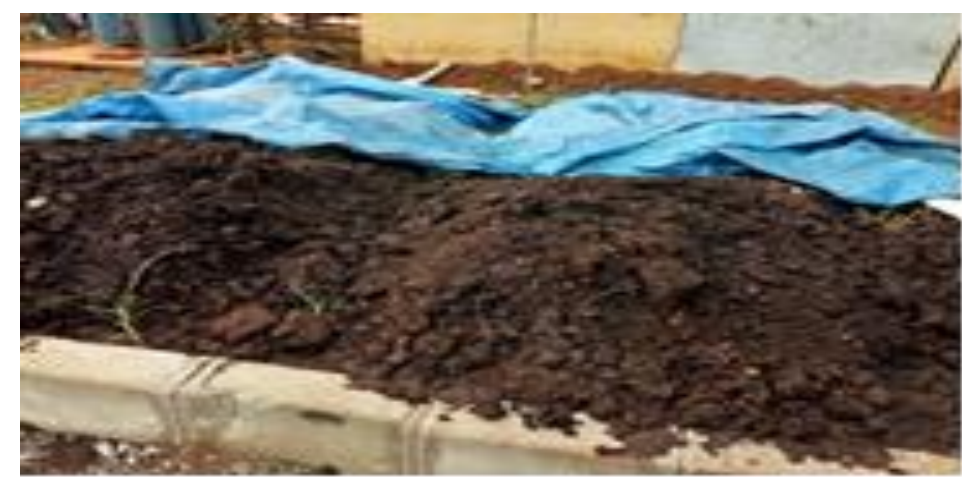

Fig. 1: Compost was made from dregs tea of water-solvent in PT Indesso Aroma

The dregs tea from alcohol-solvent extraction when made into a fertilizer, does not show success even though it has been incubated for a month. It caused by the presence of alcohol which is toxic to plant roots in concentrations as low as $1 \mathrm{ppm}[8]$.

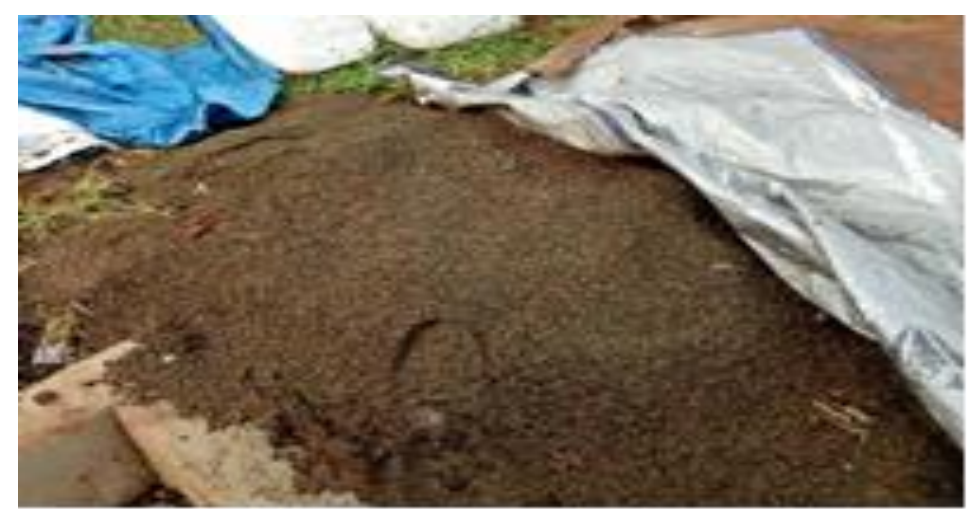

Fig. 2: Compost was made from dregs tea of alcohol-solvent extraction in PT Indesso Aroma

\subsection{Briquette from Tea Waste}

Consideration to utilize tea waste into briquettes is because the briquette machine can accept a lot of inputs so it is very effective to reduce the organic solid waste. The dregs tea at PT Indesso Aroma in a day can reach $1000 \mathrm{~kg}$ so if left unchecked it will take a lot of land and someday will be needed expansion of land to accommodate all the solid waste. The process is also quite easy and raw materials are available for free. This utilization is expected to help consideration in the purchase of briquette machine as a way to overcome the problem of solid waste.

The making of briquettes made from raw tea leaf waste was done at R \& D Forestry Laboratory, Bogor, west 
java, Indonesia. The raw material provided has a water content of decrease from $50 \%$ into $18.75 \%$ after drying under the sun. From 1255 grams gross weight of tea waste can be used as charcoal for 447 grams. The resulting yield is $42 \%$ of the ratio of the char yield to the dry weight.

TABLE III: The results of caloric test of briquettes made from dregs tea

\begin{tabular}{|c|c|c|c|}
\hline Sampel & Charcoal from Dregs Tea & Briquette making & $\begin{array}{c}\text { Calorific } \\
\text { value }(\mathrm{Cal} / \mathrm{g})\end{array}$ \\
\hline \multirow{5}{*}{ Dregs tea } & Wet-weight $=1255$ grams & Charcoal $=200 \mathrm{~g}$ & \multirow{5}{*}{5544.638} \\
\hline & Water content $=18.75 \%$ & Water $=150 \mathrm{CC}$ & \\
\hline & $\begin{array}{c}\text { Dry-weight }=1056.84 \\
\text { grams }\end{array}$ & Starch $=5 \%$ & \\
\hline & Charcoal $=447$ grams & & \\
\hline & Yields $=42 \%$ & & \\
\hline
\end{tabular}

The calorific value of the briquettes is 5544,638 cal / $\mathrm{g}$. The calorie value is in accordance with SNI 1-62352000 which says that minimum calorific value (on the basis of dry weight) of a briquette as a fuel is $5000 \mathrm{cal} / \mathrm{g}$. The value of $5544,638 \mathrm{cal} / \mathrm{g}$ is in class $\mathrm{C}$ based on the briquette classification based on the heating value. It can be seen in Table 4.

TABLE IV: The brick classification based on calorific value

\begin{tabular}{|c|c|}
\hline Classes & The Range of Calorific Values (kal/g) \\
\hline A & $>6200$ \\
\hline B & $5600-6200$ \\
\hline C & $4940-5600$ \\
\hline D & $4200-4940$ \\
\hline E & $3360-4200$ \\
\hline F & $2400-3360$ \\
\hline G & $1300-2400$ \\
\hline
\end{tabular}

Source :Hartanto and Alim 2011

In Indonesia, charcoal briquettes and grass briquettes do not yet have a standard, but quality standards for wood raw materials, hard shells, and coconut shells have the standard in number SNI 01-6235-2000 as shown in Table 5. The calorific value of dregs tea meets national standards for briquettes. However, if you want to be commercialized, it is necessary to conduct other briquette quality tests such as ash content, moisture content, and missing parts on heating $9500 \mathrm{oC}$.

TABLE V: Quality of briquettes based on sni 01-6235-2000

\begin{tabular}{|l|c|}
\hline \multicolumn{1}{|c|}{ Parameter } & SNI 01-6235-2000 \\
\hline Water Content $(\%)$ & $\leq 8$ \\
\hline Ash Content $(\%)$ & $\leq 8$ \\
\hline Missing part on heating $950^{\circ} \mathrm{C}(\%)$ & $\leq 15$ \\
\hline Calorific value $(\mathrm{kal} / \mathrm{g})$ & $\geq 5000$ \\
\hline
\end{tabular}

Comparison is done between coal briquettes, wood charcoal, and tea briquettes because briquettes are often used in the community as a fuel. In addition to calorific test, it is also necessary to test briquette combustion to determine the color of fire and smoke. The calorific value is an important parameter because it affects the efficiency of briquette fuel. The greater the calorific value the amount of fuel needed to generate heat will be less. The calorific value can be analyzed using bomb calorimeter [9]. 

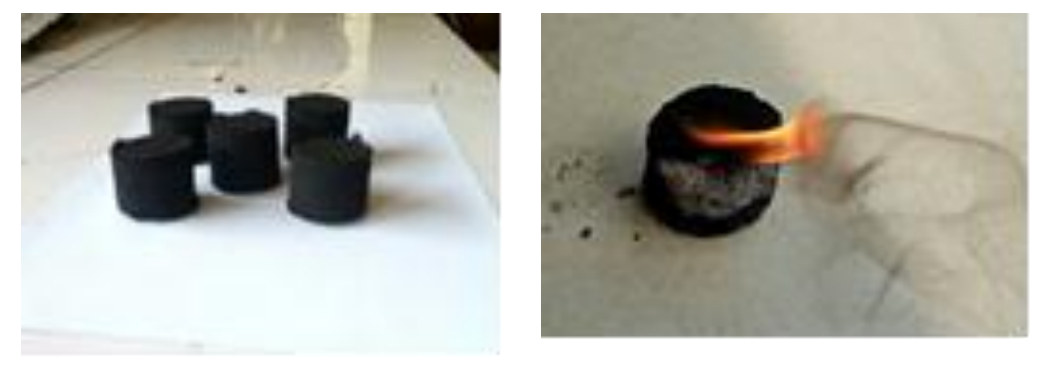

Fig. 3: Fire and smoke resulting from burning dregs tea briquettes

\subsection{Super Capacitor Based on Activated Carbon}

Super capacitor is an energy storage device that saves energy electrostatically by polarizing an electrolyte compound. Super capacitor consists of 2 electrodes, 1 electrolyte compound, and 1 electric insulator separator. Electrode function as an electric conductor or a media for electric current to pass through. Electrolyte is a substance that act as an electrical conductor when dissolved in a polar solvent. Electric insulator acts as a separator which separate electrolyte with different charges.

Super capacitor has higher capacitance and higher power density than normal capacitor and battery. Battery has high capacitance but low power density. Normal capacitor has high power density but low capacitance. Power density refers to power or quantity of Watts while capacitance refers to how long the storage device can be used. Super capacitor has the advantage of longer life, simple principle and model, short-time charging, safe, and able to have 10-100 times higher power density [10].

Super capacitor is divided into 2 types: Double layer capacitor and Pseudo capacitor. Double Layer Capacitors use carbon as its electrode. Pseudo Capacitors use metal oxide and polymer as its electrode [11]. The difference is shown on Fig 4. Specification for super capacitor can be found on Table 6.

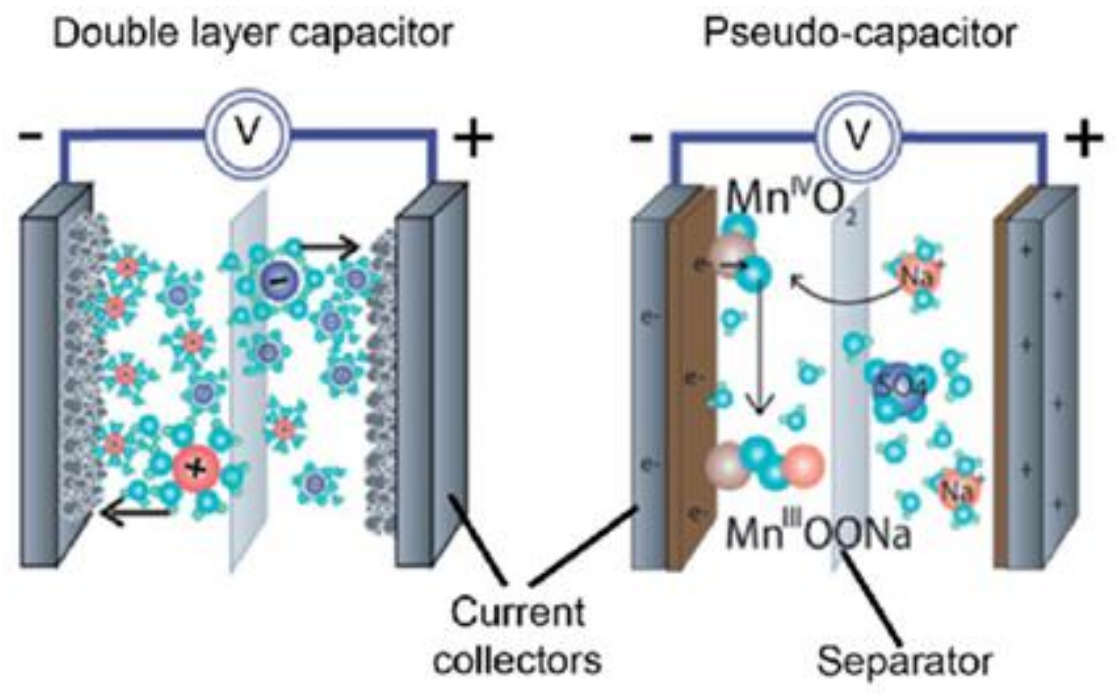

Fig. 4: The difference between double layer capacitor and Pseudo capacitor [12] 
TABLE VI: General specification for super capacitor [13]

\begin{tabular}{|c|c|}
\hline Parameter & Rating \\
\hline Capacitance tolerance & $-20 \% /+80 \%$ \\
\hline Capacitance range & $7 \mathrm{mF}$ to $700 \mathrm{mF}$ \\
\hline ESR range & $18 \mathrm{~m} \Omega$ to $1200 \mathrm{~m} \Omega$ \\
\hline Working Voltage & $0.7-18$ volts \\
\hline Power & 10 's of Watts, short pulse widths \\
\hline Foot Print & $\begin{array}{c}12 \times 12.5 \mathrm{~mm}, 10 \times 15 \mathrm{~mm}, 17 \mathrm{x} 17.5 \mathrm{~mm}, 28 \times 17.5 \\
\mathrm{~mm}, 48 \times 30.5 \mathrm{~mm}\end{array}$ \\
\hline Operating temperature & $-40^{\circ} \mathrm{C}$ to $+70^{\circ} \mathrm{C}(\mathrm{CLG}$ and $\mathrm{CLC}$ series $)-40^{\circ} \mathrm{C}$ to \\
$+85^{\circ} \mathrm{C}(\mathrm{CLK}$ series $)$
\end{tabular}

Activated carbon is divided into 2 types: activated carbon for liquid phase and gas phase. Activated carbon for liquid phase is usually found in powder form. This kind of activated carbon can be made of materials that have low density (in example woods, coals, and materials containing lignin). Activated carbon for liquid phase is used for solution purification and taste and smell removal on liquid solution. Activated carbon for gas phase has the granules form. Activated carbon for gas phase can be made of materials that have higher density (in example coconut shells and petroleum residue) and used in gas and steam adsorption.

Activated carbon as electrode is because activated carbon has the biggest surface area than other carbon material. Surface area affects the adsorption ability of one material. The bigger the surface area is the better the adsorption will be. In super capacitor, adsorption is used to collect charges from electrolyte.

There are 3 steps on how to make activated carbon: dehydration, carbonization, and activation. Dehydration is the process to lose water content inside the raw material. Carbonization is the process to decompose organic material through pyrolysis at $500-800 \mathrm{oC}$ [14]. Activation is the process to improve the activated carbon's adsorption ability by draining steam or $\mathrm{CO} 2$ into the carbon at $800-1100 \mathrm{oC}$ [15]. Activated carbon specification can be found on Table 7.

TABLE VII: Activated carbon spesification [16]

\begin{tabular}{|c|c|}
\hline ITEM & Standard \\
\hline Particle Size & $8-32 \mathrm{Mesh}$ \\
\hline Methylene Blue Decolorization & $>150 \mathrm{mg} / \mathrm{g}$ \\
\hline Iodine adsorption & $>1000 \mathrm{mg} / \mathrm{g}$ \\
\hline Dry Weight Reduction & $<5 \%$ \\
\hline $\mathrm{Ph}$ & $4-11$ \\
\hline Chloride & $<0.5 \%$ \\
\hline Lead $(\mathrm{Pb})$ & $<10 \mathrm{ppm}$ \\
\hline Zinc $(\mathrm{Zn})$ & $<50 \mathrm{ppm}$ \\
\hline Cadmium $(\mathrm{Cd})$ & $<1 \mathrm{ppm}$ \\
\hline Arsenic $(\mathrm{As})$ & $<2 \mathrm{ppm}$ \\
\hline
\end{tabular}


Charcoal resulting rom the carbonation of the the tea waste in PT Indesso Aroma, it can be used as an electrode for super capacitor. The charcoal need to be activated first before it can be used as a electrode for the layer of its capacitor. This utilization is done to increase the value of charcoal.

\section{Conclusion}

One of the products of plant extraction in PT Indesso Aroma is tea. From the tea extraction process is produced waste in the form of dregs tea. The solid waste continues to increase over time so that the dregs tea will accumulate and narrow the landfills. So it is necessary to solve the problem by reprocessing the solid waste into a useful material such as fertilizer and charcoal briquettes. For water-solvent extraction, dregs can still be used as fertilizer and waste extracted while alcohol can be used as briquettes. Preparation of fertilizer with raw materials of tea waste in PT Indesso Aroma has NPK content in accordance with the minimum limit according to SNI. Nitrogen concentration of tea leaf waste fertilizer is $1.73 \%$ (as shown in table 1) and in accordance with the minimum of SNI, the content of $\mathrm{N}$ in compost is $0.4 \%$. Potassium concentration seen from $\mathrm{K} 2 \mathrm{O}$ content is $0.38 \%$ and in accordance with the minimum of SNI, $\mathrm{K} 2 \mathrm{O}$ content in compost is $0.2 \%$. Then the concentration of phosphorus seen from the content of $\mathrm{P} 2 \mathrm{O} 5$ is $0.56 \%$ and in accordance with the standard SNI at minimum limit in $0.1 \%$.

Utilization of dregs tea into briquettes is the most effective way to overcome the problem of tea waste accumulation in PT Indesso Aroma. Although there is considerable investment on the machine, it can produce more than $1000 \mathrm{~kg}$ briquettes per day. Making briquettes made from the dregs tea at R \& D Forestry Laboratory, Bogor. Analysis of briquette calorific content to know the quality of briquettes. According to the caloric test, tea briquettes have calories of 5544,638 calories / gram, while the minimum limit of caloric briquettes made from organic raw is 5000 calories / gram, already accordance to SNI.

Super capacitors are energy storage devices that store energy electrostatically by polarizing an electrolyte compound. Electrochemical Double Layer Capacitor or super capacitor is an electrochemical capacitor that has high capacity and high energy density compared to regular capacitors and batteries. The super capacitor consists of 2 electrodes made of activated carbon, 1 electrolyte compound, 1 ion-removable separator but provides electrical insulation. Charcoal resulting rom the carbonation of the the tea waste in PT Indesso Aroma, it can be used as an electrode for super capacitor. The charcoal need to be activated first before it can be used as a electrode for the layer of its capacitor. This utilization is done to increase the value of charcoal.

\section{References}

[1] Business for Social Responsibility (BSR), The New Frontier in Sustainability, The Business Opportunity in Tackling Sustainable Consumption, 2010.

[2] R Malone, World's Worst Waste. Forbes, Opinion Section, 2006 May $24 . \quad$ Available from: https://www.forbes.com/2006/05/waste-worlds-worst-cx_rm_0524waste.html\#79bf31f23d79 [accessed 13 Mar, 2018].

[3] Jill Chin, Issues for Responsible Investors Waste in Asia. [www.responsibleresearch.com], 2011.

[4] A Kafeel and A Pervez, "Impact of Solid Waste on Health and The Enviroment," Journal of Sustainable Development and Green Economics, vol. 2, pp. 165-168, 2013.

[5] S Puguh, "Extraction of Phenolics Compounds from Green Tea Using Ethanol," Journal of Engineering and Applied Sciences, vol. 9, pp. 1516-1521, September 2014.

[6] T. Sun, B.L. Pan,Y. Huo,S.M. Guan, and Y. He, "Isolation and Bioactivies of Main Functional Components in Tea," Chem. J., vol. 26, pp. 2191-2198, April 2014.

[7] A Monks, Market Alternatives for Japanese Green Tea. Australia: Rural Industries Research and Development Corporation,2000. 
[8] H Garrett, J Ferguson, M Amaranthus , Organic Management for the Professional: The Natural Way for Landscape Architects and Contractors, Commercial Growers, Golf Course Managers, Park Administrators, Turf Managers, and Other Stewards of the Land, University of Texas Press, 2012

[9] FP Hartanto and F Alim, "Optimasi Kondisi Pirolisis Sekam Padi untuk Menghasilkan Bahan Bakar Briket Bioarang sebagai Bahan Bakar Alternatif”, Universitas Dipenogoro, 2011

[10] Kay Hyeok, An. "Electrochemical Properties of High-power Supercapacitors Using Single-Walled Carbon nano tube Electrodes", Advanced Functional Materials vol. 3 p. 387-392. 2001.

[11] Vikram and Yadav S. "The Effect of Frequency and Temperature on Dielectric Properties of Pure Poly Vinylidend Fluoride (PVDF) Thin Films". Proceedings of world congress on engineering 2009, London (UK): vol. 1 p. $400-402$. 2009.

[12] Next-generation textiles: from embedded supercapacitors to lithium ion batteries - Scientific Figure on ResearchGate. Available from: https://www.researchgate.net/Comparison-between-double-layer-capacitor-pseudo-capacitor-andlithium-ion-battery_fig2_309638024 [accessed 20 Mar, 2018].

[13] Cellergy Ltd. Supercapacitor Product Specification Rev 35, 2013.

[14] Marsh H and Francisco RR. Activated Carbon. Amsterdam: Elsivier Science and Technology Books. 2006.

[15] Budiono A, Suhartana, Gunawan, Pengaruh aktivasi arang tempurung kelapa dengan asam sulfat dan asam fosfat untuk adsorpsi fenol. University of Dipenogoro, 2009

[16] Idaman, N S. "Pengolahan Air Minum dengan Karbon Aktif Bubuk. Pusat Teknologi Lingkungan”, BPPT. 2007, vol. $3(2)$. 